\title{
The Cyprus Talks 2015-2017: Their Course, the Outcome, and Consequences for the European Union ${ }^{1}$
}

\section{Introduction}

The main aim of the article is to present political consequences of the failure of the Cyprus talks 2015-2017 for the European Union. Although its institutions and representatives were engaged in the negotiation process there, the issue seems to be more complex when it comes to defining what their role was. One can find the answer to such a question analysing the course and the final outcome of the negotiation process in Cyprus.

The European Union is often referred to as a peace promoter. This element constitutes a significant part of the bigger concept related to the Union's external actions, namely the EU's role as a security provider. In the case of Cyprus, however, the division on the island remains an internal and external challenge to the EU security and prosperity. As a result, the EU is in a position in which it has to promote peace not only outside, but also within its own borders. It is a direct consequence of the decisions which were made in 2003. When the Republic of Cyprus was accepted as an EU member state, the whole Cypriot territory became a part of the Union's territory. The main difference is that the application of acquis communautaire "in those areas of the Republic of Cyprus in which the Government of the Republic of Cyprus does not exercise effective control" has been suspended on the basis of article 1 of Protocol 10 to the Accession Treaty of 2003 (Protocol 10, 2003). In practice, the de facto division of the island continues with all that this situation implies. There is nothing the EU or the Republic of Cyprus could gain without prior consultations and compromise with the Turkish Cypriot leadership and Turkish authorities. In addition, "neither the legal writ of the Republic of Cyprus nor of the European Union holds effectively over the north, whilst at the same time there have been important concrete de facto relations, economic relations included, between them and TRNC" (Ekici, 2019, p. 35).

The main research questions are as follows: What was the course of bicommunal negotiations? What brought the negotiations to a halt in 2017? How did the European

${ }_{1}$ The article was written as part of a project co-founded by the Erasmus+ Programme of the European Union "Jean Monnet Center of Excellence EU EX/ACT- EU External Actions in the contested global order - (in)coherence, (dis)continuity, resilience" DISCLAIMER: The European Commission support for the production of this publication does not constitute an endorsement of the contents which reflects the views only of the authors, and the Commission cannot be held responsible for any use which may be made of the information contained therein. 
Union engage in the process? What are political consequences of the talks failure for the European Union? The selected research method is sources analysis and the research technique is qualitative content analysis. On this basis one can study, for example, selected speeches, declarations as well as official documents. As regards the main sources, these are selected EU and UN documents, monographs, and academic articles.

\section{The Cyprus Talks 2015-2017}

The so-called Annan Plan was presented as the best ever opportunity to solve the Cyprus problem. This illusion shattered with the failure of the 2004 referenda. Soon after that some analysts suggested that the peace process should be pursued only by leaders of both Cypriot communities without any significant interference of third parties. As a result, the "Cypriot ownership of the negotiations" was initiated in 2008 "as an alternative to the previous UN-led process" (Ioannou, 2017). After the failure of 2008-2012 talks, both sides attempted to renew negotiations two years later. In February 2014 Turkish Cypriot leader Dervis Eroglu and Greek Cypriot leader Nicos Anastasiades announced the signing of a joint declaration. The most important issue was addressed in the first point: "The status quo is unacceptable and its prolongation will have negative consequences for the Greek Cypriots and Turkish Cypriots" (Joint declaration, 2014). Yet the most adverse provision was mentioned in point 5, according to which nothing was agreed until everything was agreed (Joint declaration, 2014). Such an assumption undermined the whole peace process as it became clear that both leaders would be able to quit the talks until the last day even if almost everything was already agreed. The process was officially supported by Greece, Turkey, and the European Union. Yet the 2014 talks broke off when a Turkish warship entered territorial waters controlled by the Republic of Cyprus. This action was an element of the crisis over the exploration of natural gas deposits in the Eastern Mediterranean. The situation changed only when Mustafa Akinci was elected the president of the TRNC in April 2015.

As a consequence, the 2015-2017 talks were initiated by President of the Republic of Cyprus Nicos Anastasiades and President of the Turkish Republic of Northern Cyprus Mustafa Akinci. Both leaders represented their respective communities. The main negotiation objective was to reach a mutually beneficial solution and end the division of the island. At the same time, concerns about the ability to achieve a compromise arose. The history of bilateral negotiations in Cyprus was the history of high hopes, great expectations, big disappointments, and missed opportunities. Analysts and commentators pointed to the previous negotiation rounds between 2000-2004 and 2008-2012. In both cases Greek Cypriots and Turkish Cypriots were close to the conclusion of a comprehensive agreement. Yet the negotiations broke down twice at the last moment despite significant support of the United Nations and the European Union. Such developments only confirmed the validity of a popular saying that Cyprus is the graveyard of diplomats (Martin, 2006; Lindahl, 2019).

However, despite such a negative record, both Cypriot leaders opened a new round of talks with a very positive attitude. Most of commentators pointed to Akinci's presi- 
dential victory in 2014 as a key moment which had opened a way to the reopening of bilateral negotiations in 2015. Without any doubt, the new Turkish Cypriot leader was much more interested in the peace process than his predecessor Dervis Eroglu. In addition to that, Akinci intended to pursue a policy that would be less dependent on Turkey. If one added Anastasiades' positive approach to the bicommunal dialogue, everything indicated that it was the best moment to open negotiations and reach a comprehensive agreement.

The UN Secretary General sent his special envoy - Espen Barth Eide, Norway's former defence and foreign affairs minister, to support the bicommunal negotiations. At the same time the peace process was supported by the European Commission. On 17 July 2015 President Jean-Claude Juncker openly declared: "And after unification - the next time I will come here will be after the reunification - Cyprus will not be left alone when implementing a settlement. The European Union is - I believe and I hope - a Union of everlasting solidarity, so we will help you meet these challenges of reuniting the country. Be assured you will not walk alone" (Cyprus Settlement, 2017). Such a declaration was a clear message to both Cypriot leaders. The agreement was to become the first step toward the normalization of bicommunal relations on the islands. During the process both Greek and Turkish Cypriots were to receive a significant support from the EU institutions.

At the very beginning of the talks, both leaders focused mainly on such issues as citizenship, governance, and the future status of the so-called Turkish settlers, namely Turkish citizens who came and settled in North Cyprus after 1974. Most importantly Akinci and Anastasiades agreed that the talks should lead to the establishment of a bizonal and bicommunal federal state. The same provision constituted the core element of the so-called Annan Plan in 2004. Positions of both parties on the most important matters were, however, mainly divergent. As a consequence, both parties engaged in negotiations dedicated to the following chapters:

- governance and power-sharing;

- federal competencies, coordination between the federal government and two constituent states, and all issues related to citizenship;

- economic issues, including fiscal federalism, taxation, public debt, monetary policy, and economic convergence;

- property;

- security and guarantees;

- territorial aspects (Report, 2017).

The two rounds of talks were held in the Swiss town of Mont Pelerin in November 2016. Both sides focused mainly on territorial issues. Unfortunately, the negotiations were brought to a halt due to the large disparities between representatives of the two Cypriot communities.

The 2017 Conference on Cyprus in Geneva could have become a milestone in the history of bicommunal negotiations. The event was convened under the auspices of the UN Secretary General. Among the main participants were leaders of both communities, ministers of foreign affairs of Greece, Turkey, and the United Kingdom. In addition, the European Union was represented in Switzerland as an observer. According to an official UN note to correspondents, which was released on 12 January 2017, "the 
discussions underscored the participants' intention to find mutually acceptable solutions on security and guarantees that address the concerns of both communities. They recognized that the security of one community cannot come at the expense of the security of the other. They also acknowledged the need to address the traditional security concerns of the two communities while at the same time developing a security vision for a future united federal Cyprus" (Note, 2017). Accordingly, the Geneva meeting was presented as a significant breakthrough. Yet Cypriots have witnessed a lot of such breakthroughs in their history since 1974. Everything depended again on the good will of both sides. Nobody could have been sure of the final outcome until the last minute.

Although the conference in Geneva was presented as a diplomatic success, it did not result in any breakthrough. Quite the opposite, instead of the progress in the talks, the situation deteriorated suddenly. The talks came to a halt again in February 2017 when Greek Cypriot parliamentarians voted to introduce an annual commemoration of the 1950 referendum in public schools. The referendum supported the idea of Cyprus' reunification with Greece and was condemned by Turkey and Turkish Cypriots at that time mainly because they interpreted this step as a political provocation. At the same time the Greek Cypriot side claimed that Turkish Cypriots broke the negotiations in an effort to stall the talks ahead of Turkey's constitutional referendum in April (Gramer, Surana, 2017). As a matter of fact, the negotiations were resumed in April 2017. Antonio Guterres also invited both leaders to New York where they were to discuss the possibility to reconvene the conference. There they made a decision to meet in the town of Crans-Montana in the end of June.

When representatives of all parties arrived in Switzerland, Antonio Guterres provided them with the framework paper including the key aspects. The conference was organised in a 'two-table' format. The main assumption was that Cypriot leaders could discuss issues related to territory, property, equal treatment, and power-sharing at the first table. The talks at the second table were to be dedicated to security and guarantees (Report, 2017). This one was intended for Akinci, Anastasiades, representatives of the three guarantor powers, namely Greece, Turkey, and the United Kingdom as well as for the European Union as an observer. The Cypriot leaders, however, were unable to reach any compromise during the talks. The security issues, especially a new military arrangement on the island, became the key divisive aspects (Ioannou, 2017; Christou, 2017). Unfortunately, it soon appeared that it was a closed-door situation. The negotiations broke down after seven days despite a positive mood and constructive declarations that had been made on the opening day.

Soon after the failure of talks in Crans-Montana, the UN Secretary General published a detailed report on his mission of good offices in Cyprus between 2015-2017. In this document he pointed to the main reasons for the diplomatic failure. Guterres concluded his assessment of the situation on the island as follows: "the essence of a comprehensive settlement to the Cyprus problem is practically there. The parties had come close to reaching a strategic understanding on security and guarantees, as well as on all other outstanding core elements of a comprehensive settlement. It is therefore my firm belief that a historic opportunity was missed in Crans-Montana" (Report, 2017). The pessimistic tenor of the report was probably the best description of the status quo on the island. 
The situation has not changed since then. In June 2018 Antonio Guterres, presented another report on his mission of good offices in Cyprus. He noticed as follows: "Interest in the Cyprus problem has noticeably waned, as citizens' belief in a possible settlement in the near future seems to have sharply diminished on both sides. Notwithstanding repeated encouragement from the international community, the leaders have not taken new trust-building or confidence-building measures, even though a number of such initiatives could be implemented jointly or unilaterally" (Report, 2018). The pessimistic tone of the Secretary General's conclusions only proved that the atmosphere on the island had deteriorated significantly since the diplomatic failure in Crans-Montana.

Between 2015-2017 both Cypriot leaders met 70 times and their negotiators held more than 150 meetings (Report, 2017). If such a diplomatic effort did not result in any significant progress, the current scepticism regarding the resumption of substantial negotiations is completely understandable. As a consequence, the current situation in Cyprus resembles the developments which took place after the previous unsuccessful negotiation rounds, for example, in 2004 or in 2012. In the opinion of Michalis S. Michael and Yucel Vural, "leader led and far removed from Cypriot reality, the talks acquired a rather detached demur from the everyday. In terms of content, the talks had indeed generated unprecedented substantive progress, eventually tackling the rather thorny territorial chapter before faulting on the insurmountable security and guarantee issues" (Michael, Vural, 2018, p. 5).

The role of Turkey in the talks cannot be underestimated. Although it would not be fair to blame Ankara for the ultimate failure, the Turkish position is not coherent anymore. According to Altug Günal, "it is not possible to claim that Turkey has a coherent policy on Cyprus. Over time, it has swung from indifference to partition, federation to confederation, national cause to national burden, and 'no solution is a solution' to 'being always one step ahead' in the search for a solution" (Günal, 2018, pp. 57-58).

\section{The EU's Role in the Negotiation Process}

According to the key arrangements, both Cypriot leaders were to agree on all negotiated matters, endorse their agreement, and promote the outcome in two simultaneous referenda (Ioannou, 2017). The last stage resembled the solution which was applied in the case of the Annan Plan in 2004. Yet this time the role of the United Nations was limited and both Akinci and Anastasiades were well aware of all consequences. If the negotiations resulted in a failure, the international community would blame the Cypriot leaders for that. The EU's role in the whole process was even more symbolic than the UN role. Yet it was obvious that Brussels backed the negotiation process and a potential success would benefit not only members of two Cypriot communities, but also the European Union as a whole. In addition, a vision of a de facto participation in European integration was to encourage not only Turkish Cypriots, but also the Turkish authorities to make their official positions more flexible.

Nikos Skoutaris underlined the fact that "both communities were hoping that the accession to the Union would have 'a catalyst effect' in order for a settlement to be achieved. The difference was that the Turkish Cypriots were hoping for this to happen 
through the Annan Plan on 24 April 2004 while the Greek Cypriots were convinced that the accession of Cyprus to the EU would catalyse a settlement that would better serve their interests at a later time" (Skoutaris, 2011, pp. 161-162). Such an attitude in studies on potential consequences of Cyprus' accession to the EU was criticized by some scholars. Wojciech Forysiński, for example, pointed to the fact that "the source of this chemical rhetoric seems to be the European Union itself which has repeatedly stated that it supported a just and lasting settlement of the Cyprus question, and that the prospect of Cyprus accession would provide an incentive for this" (Forysiński, 2008, p. 125). According to Karen E. Smith, "the prospect of membership for Cyprus was also held out partly in the hopes that it would unblock the stalemate there, but did not perhaps because the EU did not insist on a resolution of the conflict before it agreed to enlarge to the country" (Smith, 2014, p. 59).

As has been mentioned previously, the EU's engagement in the bicommunal negotiations in Cyprus was limited. Yet it did not mean that European institutions had no influence on the peace process. It was quite the opposite. The EU's influence was noticeable in two dimensions, namely in a direct engagement as well as in an indirect influence.

The first category refers to all actions undertaken either by EU officials or by EU institutions. The Union's representatives participated in the conference of Cyprus and the EU had the status of observer. The delegation was led by President Jean-Claude Juncker. Later, during the talks in Crans-Montanta in July 2017, the EU was represented in a 'two-table' format at the so-called second table. In addition, President Juncker appointed Pieter Van Nuffel as his representative to the UN Good Offices Mission in Cyprus. Van Nuffel led "a small but efficient support team of Commission officials from the Structural Reform Support Service working alongside the UN Good Offices at the UN Protected Area in Nicosia." His main task was "to provide technical and legal advice via the UN to the two sides on settlement elements which are relevant from an EU law angle" (The EU's role, 2017). Van Nuffel's team was comprised of 33 EU officials who worked both in Brussels and Nicosia. They focused mainly on the implementation of the Aid Program for the Turkish Cypriot community and of the Green Line Regulation.

The Council established an instrument of financial support for encouraging the economic development of the Turkish Cypriot community and amending Council Regulation (EC) No 2667/2000 on the European Agency for Reconstruction. In 2018 its total cost was 35 million euro. On the basis of the instrument, the EU encourages the economic development of Turkish Cypriots and this way facilitates the reunification of Cyprus. The instrument's main objectives are:

- investments in infrastructure;

- the promotion of social and economic development;

- confidence-building measures;

- promotion of European values among Turkish Cypriots;

- "preparation of legal texts aligned with the acquis communautaire";

- "preparation for implementation of the acquis communautaire in view of the withdrawal of its suspension in accordance with Article 1 of Protocol No 10 to the Act of Accession" (Council regulation, 2006). 
As regards the indirect influence of the EU, one can point to values and principles on which the EU was founded. In this case, the European Union can be seen as a soft power. During the 2015-2017 talks both leaders agreed that they will observe all principles on which the European Union was founded (Report, 2017). In addition to that, the European Commission declared "to help to prepare for the implementation of the acquis communautaire of the European Union in a future Turkish Cypriot constituent state" (Report, 2017).

In view of the above, one can conclude that the EU's engagement in the peace talks was significant and noticeable, however, it seems that the Union could have mobilised both sides to a greater extent. Given the failures of the previous UN-led negotiations as well as of the current bicommunal talks, it is high time to give serious consideration to other possible scenarios, for example, a 'Europeanization' of the peace process in Cyprus. If the EU was to become a mediator between representatives of both Cypriot communities, the main obstacle would be probably a growing distrust between the Union and Turkey. Ankara still perceives the EU to be a supporter of Greek Cypriots and Greece. For this reason, Turkey may question the Union's impartiality if the EU was to offer its good offices or mediation in the case of Cyprus. Yet the EU should make an attempt to become a real security provider not only in its immediate neighbourhood, but also in Cyprus.

\section{The Diplomatic Failure: Consequences for the EU}

The talks ultimate failure means that the Cyprus question remains unsolved and the status quo continues. Such a scenario is beneficial neither to both Cypriot communities, nor the European Union. The lack of any solution has already undermined Turkey's accession negotiations with the EU. As long as there is no rapprochement on the island and the Republic of Turkey does not establish diplomatic relations with the Republic of Cyprus, the Commission will not open talks in 8 out of 35 key areas under negotiation, which have been suspended since December 2006. At the moment such developments are welcomed by those EU leaders who would like to block the Turkish entry into the EU. Without any doubt, the Cyprus question constitutes a good excuse for them. The situation, however, may change when key member states like Germany and France change their general attitude toward the Turkish membership.

In addition, the unresolved Cyprus question further complicates EU's cooperation with NATO. On the one hand, Turkey, one of the most influential NATO member states, is not an EU member and does not recognize the Republic of Cyprus. For this reason, Ankara does not want NATO to share any sensitive data and the intelligence with the EU, because these will also become available to the Greek Cypriot authorities. On the other hand, "the Republic of Cyprus, a member of the EU but not of NATO, doesn't recognize the Turkish Cypriot north, so it blocks NATO-EU engagement from its seat at the EU" (Gramer, Surana, 2017).

What is the future? The new Turkish Cypriot coalition government, formed by National Unity Party (UBP) and People's Party (HP) in May 2019, is very sceptical about whether it would be possible to settle the dispute on the basis of any federal, bicom- 
munal concept. In its manifesto the new coalition openly declared: "The negotiation processes that have been going on for more than half a century have essentially shown that the federal partnership model, which is based on sharing power and wealth, has been exhausted and that under the current circumstances federation is not a realistic solution model" (Ambitious and proactive, 2019). Such an attitude means that the new government is ready to promote a two-state solution rather than an establishment of a federal state. Yet it will not be acceptable for the EU. It also contradicts the official position of the TRNC's President Mustafa Akinci. On 21 June 2019 the Turkish Cypriot leader invited President Nicos Anastasiades to discuss issues related to the Greek Cypriot position. He also suggested a future meeting which should be attended by representatives of three guarantor powers, namely Turkey, Greece, and the United Kingdom, as well as delegations of Greek Cypriots and Turkish Cypriots (Ioannidou, 2019). The intentions behind Akinci's initiative were clear. This way he intended to show his dissatisfaction with the policy of the new government as well as to underline the fact that the Greek Cypriot side was responsible for the dead-end in the negotiations. At the same time President Anstasiades blames Turkish Cypriots for the ultimate failure of the 2015-2017 talks what makes the current situation even more complex (Christou, 2018). For this reason the UN Secretary General wrote in his report of May 2019 as follows: "I underscore that the means for a durable solution to the Cyprus problem remains, foremost, in the parties' hands. As I have noted previously, a settlement will demand that each side accept less than the fullest measure of satisfaction on every issue. I also note that a comprehensive settlement will open up opportunities for growth, prosperity and confidence otherwise forsaken" (Report, 2019).

\section{Conclusion}

The European Union did not engage in the 2015-2017 Cyprus talks to the extent it had done it, for example, during the bilateral negotiations that had been conducted under the auspices of UN Secretary General Kofi Annan between 2000-2004. Does it mean that EU officials do not intend to support the peace process in Cyprus like they did in the past? Obviously, the answer is negative. The EU's institutions still pay attention to political developments on the island. Yet the previous failures cost the Union a lot. They reflected poorly on the EU's image worldwide. In addition, it is clear that the United Nations is still the leading organisation engaged in the peace process in Cyprus.

The unsettled Cyprus question still poses a challenge to the European Union. A more proactive attitude of the EU would be needed in order to maximise the chances of achieving a sustainable compromise. Nowadays the unsettled Cyprus problem may be in line with political interests of some EU members states which use the dispute to block the accession negotiations with Turkey. The situation may, however, change in the future. Then the Cyprus division may not only block the Turkish accession, but also seriously undermine the EU's position in the Eastern Mediterranean.

Some experts and analysts predicted that the Greek elections in July 2019 would give a new impetus to the Cyprus talks (Nicosia expects, 2019). Yet at least for the moment there is no indication that the Greek elections had any impact on the negotiations. 
As more time passes, it becomes more and more clear that both communities are satisfied with the current status quo and the island's division is deepening. Such a process may lead to irreversible changes. On the one hand, the basis of the next negotiation round might be a two-state principle rather than a bicommunal and bizonal federation. Although it is hard to assume that the EU would accept such an approach to the Cypriot problem, there may be no other realistic option on the table. On the other hand, maybe it is high time to "Europeanize" the peace process in Cyprus? After the failures of the UN-led negotiations and of the bicommunal talks, it is high time to leverage the potential of the European Union as a peace promoter. President Juncker's words of 14 September 2016, "to remember that Europe is a driving force that can help bring about the unification of Cyprus - something I am supporting the two leaders of Cyprus in" (Cyprus settlement, 2017), suddenly became very meaningful.

\section{Bibliography}

Ambitious and proactive: Özersay steps into limelight (2019), “Cyprus Mail”, 23.06.2019.

Christou J. (2018), Anastasiades: failure of talks not Greek Cypriots'fault, “Cyprus Mail”, 30.05.2018.

Christou J. (2017), Details of the framework paper issued by UN Secretary General, "Cyprus Mail”, 5.07.2017.

Council Regulation (2006) No. 389/2006 of 27 February 2006 establishing an instrument of financial support for encouraging the economic development of the Turkish Cypriot community and amending Council Regulation (EC) No 2667/2000 on the European Agency for Reconstruction, https://ec.europa.eu/info/sites/info/files/2018-aid-programme-annex_en.pdf, 15.07.2019.

Cyprus Settlement Process Under the Juncker Commission: A Timeline (2017).

Ekici T. (2019), The Political and Economic History of North Cyprus: A Discordant Polity, Palgrave Macmillan, Cham.

Forysiński W. (2008), The Europeanization of the Cyprus Problem: Beyond the Catalyst Effect, in: Proceedings of the Sixth International Congress on Cyprus Studies, ed. Ü. V. Osam, Eastern Mediterranean University Publications, Famagusta.

Gramer R., Surana K. (2017), Cracking the Cyprus Code, "Foreign Policy", 14.03.2017.

Günal A. (2018), What does Turkey want from Cyprus?, in: Cyprus and the Roadmap for Peace: A Critical Interrogation of the Conflict, eds. M. S. Michael, Y. Vural, Edward Elgar Publishing, Cheltenham.

Ioannou G. (2017), The Cyprus Negotiations: What Went Wrong, IPI Global Observatory, https:// theglobalobservatory.org/2017/07/cyprus-peace-process-greece-turkey/, 11.07.2019.

Martin H. (2006), Kings of Peace, Pawns of War: The untold story of peace-making, Continnuum, London.

Ioannidou L. (2019), Akinci calls on Anastasiades to participate in five-party meeting, "Cyprus Mail”, 21.06.2019.

Joint declaration on Cyprus (2014), UN Cyprus Talks, http://www.uncyprustalks.org/11-february2014-joint-declaration-on-cyprus/, 9.07.2019.

Lindahl I. (2019), Notes from the Graveyard of Diplomats: Cyprus 2002-2004, Heterotopia, Nicosia.

Michael M. S.; Vural Y. (2018), A new approach to an old conflict-identyfing the problem and imagining a solution, in: Cyprus and the Roadmap for Peace: A Critical Interrogation of the Conflict, eds. M. S. Michael, Y. Vural, Edward Elgar Publishing, Cheltenham. 
Nicosia expects momentum on Cyprus talks after Greek elections (2019), “Cyprus Mail”, 7.07.2019.

Note to Correspondents - Statement from the Conference on Cyprus (2017), United Nations Secretary General, https:/www.un.org/sg/en/content/sg/note-correspondents/2017-01-12/notecorrespondents-statement-conference-cyprus, 14.07.2019.

Protocol 10 on Cyprus (2003), Official Journal L 236, 23.9.2003, p. 955.

Report of the Secretary General on his mission of good offices in Cyprus (2017), S/2017/814, 28.09.2017.

Report of the Secretary General on his mission of good offices in Cyprus (2019), S/2019/322, 16.04.2019.

Report of the Secretary General: Progress towards a settlement in Cyprus (2018), S/2018/610, 14.06.2018.

Skoutaris N. (2011), The Cyprus Issue: The Four Freedoms in a Member State Under Siege, Hart Publishing, Oxford.

Smith K. E. (2014), European Union Foreign Policy in a Changing World, Polity Press, Cambridge.

The EU's role in the Cyprus Settlement Process: Questions and Answers (2017), European Commission, http://europa.eu/rapid/press-release_MEMO-17-52_en.htm.

\section{Summary}

The main aim of the article is to present political consequences of the failure of the Cyprus talks 2015-2017 for the European Union. Although its institutions and representatives were engaged in the negotiation process there, the issue seems to be more complex when it comes to defining what their role was. One can find the answer to such a question analysing the course and the final outcome of the negotiation process in Cyprus.

The main research question are as follows: What was the course of bicommunal negotiations? What brought the negotiations to a halt in 2017? How did the European Union engage in the process? What are political consequences of the talks failure for the European Union? The selected method is sources analysis and the technique is qualitative content analysis. On this basis one can study, for example, selected speeches, declarations as well as official documents. As regards the main sources, these are selected EU and UN documents, monographs, and academic articles.

Key words: the Cyprus question, Cyprus talks, the European Union, Cyprus, negotiations, the United Nations

\section{Rokowania cypryjskie 2015-2017. Przebieg, rezultat oraz konsekwencje dla Unii Europejskiej}

\section{Streszczenie}

Głównym celem niniejszego artykułu jest przedstawienie politycznych konsekwencji niepowodzenia negocjacji pokojowych na Cyprze w latach 2015-2017 dla Unii Europejskiej. Chociaż przedstawiciele Unii oraz jej instytucji byli zaangażowani w proces negocjacyjny, pozostaje pytanie o rolę, jaką odegrali w jego ramach. Aby znaleźć odpowiedź na to pytanie, należy przeanalizować zarówno przebieg, jak i rezultat prowadzonych rozmów.

Główne pytania badawcze brzmią następująco: jaki był przebieg rozmów pomiędzy przedstawicielami obu cypryjskich społeczności? Co zdecydowało o ich niepowodzeniu i zerwaniu 
w 2017 toku? W jaki sposób Unia Europejska zaangażowała się w dialog pomiędzy stronami? Jakie są konsekwencje braku porozumienia dla UE? Wybraną metodą badawczą jest analiza źródeł, natomiast techniką badawczą - jakościowa analiza treści aktów prawnych, monografii i artykułów naukowych. Podstawę źródłową stanowią wybrane dokumenty Unii Europejskiej i Organizacji Narodów Zjednoczonych, monografie i opracowania oraz artykuły naukowe.

Słowa kluczowe: kwestia cypryjska, negocjacje pokojowe na Cyprze, Unia Europejska, Cypr, negocjacje, Organizacja Narodów Zjednoczonych 
